\title{
Road Maps for Water Accounting Designing and Institutionalizing for Sustainable Water Management in MENA Region
}

\author{
Amgad Elmahdi* \\ Head of MENA Region- International Water Management Institute, Egypt
}

Submission: November 14, 2019; Published: November 18, 2019

*Corresponding author: Amgad Elmahdi, Head of MENA Region- International Water Management Institute, Egypt

Keywords: Water management; Sustainable development goals; Institutionalised; Hydrology; Hydrogeology; Economy; Environment; Social

\section{Opinion}

For centuries, the control and delivery of water without the appropriate institutional framework has changed states and economies in many parts of the world. In the 20th century, infrastructure development tamed key river systems and led to huge expansion in irrigation, while population nearly quadrupled. Despite important advances in water management, MENA region is thus becoming a hotspot of challenges posed by goals of sustainable water use. In some countries, withdrawals per capita per annum are already twice the available resources such as Egypt and Jordan. Egypt is an example with decreasing water availability per capita from the present $650 \mathrm{~m}^{3} /$ year to about $350 \mathrm{~m}^{3} /$ year in 2037 by expected population growth only. Additional water resources are challenging by natural and/or economic factors forcing water managers and politicians to advocate increasing the overall water efficiency in a sustainable manner.

Global, regional and local expertise shows that innovative technical and business solutions in combination with "Water Accounting" can result in improved water management and water security, which is central for rapid progress toward the Sustainable Development Goals (SDGs). Upscaling of these solutions requires major changes in water policy and practice supported by appropriate new instruments like Water Accounting. Water Accounting (WA) is not a new concept and tool developed to bridge the world of natural water resources management and productive water use. Water accounting mimics the financial accounting in its principles and seeks to provide comprehensive, consistent and comparable information related to water for policy- and decision-making to promote a sustainable use of water resources as well as equitable and transparent water governance among water users.

Accurate water accounting is vital for understanding hydrolog ical processes, managing water flows and inform policy dialogue about water and future planning. For this reason, various organizations, including Food and Agriculture Organization of the Unit ed Nations (FAO), other UN agencies, IHE Delft, IWMI and WWC have joined forces to develop standard frameworks for water accounting. However, implementation and adoption of any of these frameworks are hindered by lacking the institutional framework and the roadmap to develop water accounting that is tailored to the case (basin, region, country, etc). These can maximize the benefits of implementing water accounting for sustainable water management that can dealing with the many actors in the water sectors, filling the gap in water information in relation to water management and realize the polarization in the water sector in relation to water allocation and addresses the relation between soft and hard institutions.

This paper is presenting the answer for these two hindered factors by proposing the roadmap to designing a tailored water accounting system at the country level and the institutional framework (to support the institutionalization of the water accounting).

\section{Roadmap to designing a tailored water accounting sys-} tem

The proposed framework and processes for developing a tailored water accounting is summarized in the following few steps (Figure 1):

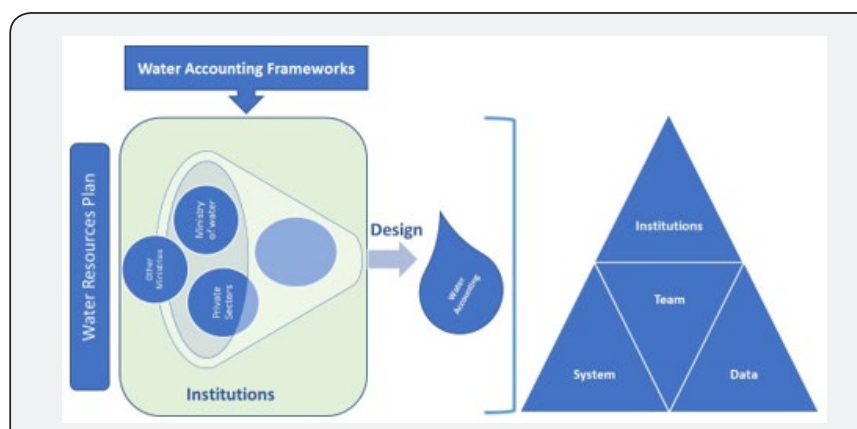

Figure 1: Water Accounting design and development roadmap. 
a) Assess all available water accounting frameworks.

b) Revisit the national water resources plan and its objectives and key questions.

c) Identify how the water accounting can evaluate the implementation of the national water resources plan.

d) Revisit the institutions (hard and soft) as enabling environment.

e) Design the water accounting system and reports that need to be supported by the water accounting unit or team.

f) Water Accounting Unit or team should have four key elements; these four elements form the key and essential structure of the unit (Institutions, System, Data and Team).

Institutions setting: provide and clarify the mandates and objective of the unit including its regulations, law, and policy

System: provide the tools/models that are using for producing the water accounting components
Data: provide the data requirements, acquirement, base, and management that support the production of the water accounting

Team: provide the human resources that produce the account and validate its inputs and outputs. The team consists of two main groups named (Analysts and Producers). These Analysts and Producers can be setting within the unit or at other stakeholders' premises where their role is to support the production of the water accounting. The roles of both Producers and Analysts are very complementary and each group is not effective without the other group. Producers provide the key technical skills required to produce the water accounting; while, Analysts provide the key insights into the inputs and outputs of the water accounting.

\section{Institutionalizing water accounting}

Institutional setting is a key element for the success of designing, implementing and producing water accounting report. Figure 2 presents the proposed institutional framework. Six steps are essential to institutionalizing the water accounting:

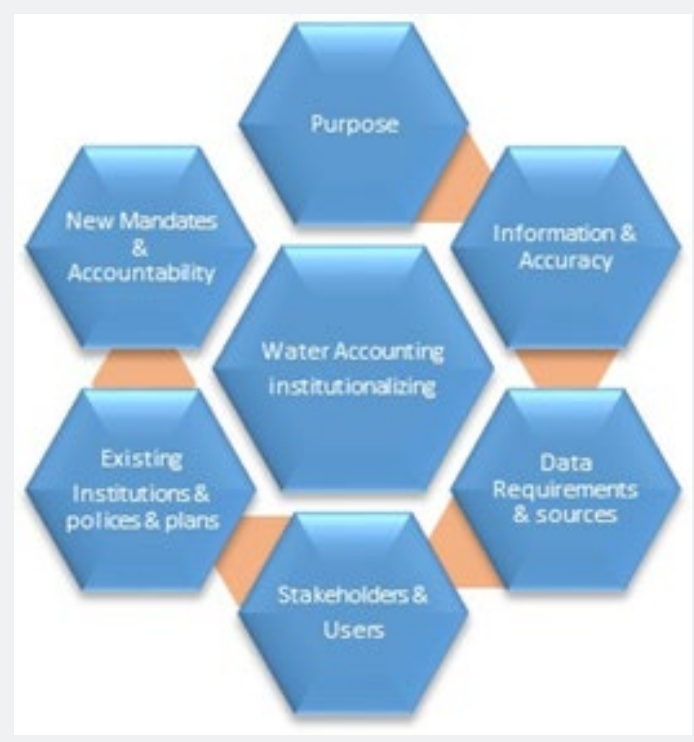

Figure 2: Institutional framework for water accounting implementation.

a) Purpose: Defining the purpose of the water accounting, what type of question that need to be answered and at what scale (spatial and temporal).

b) Information and accuracy: defining the key information and level of tolerance and accuracy of this information that will support the decision or answer the question in relation to the purpose.

c) Data requirements and sources: defining the data required and its format, frequency and quality and the sources of it in terms of location and agencies (own, collect and archive). d) Stakeholder and users: defining the key stakeholders and users through stakeholders' analysis and mapping. Also, the key users of the information and the report of the water accounting.

e) Existing institutions and policies: mapping and review the existing institutions (soft and hard) and polices to define their capacity and gap in relation to water accounting

f) New Mandates and accountability: define and design the new institution, policy, law that clarify the new mandates (soft institution) and accountability (hard institution). 


\section{Conclusion}

Water Accounting is required to be tailored, integrated, detailed, and standardised. The proposed frameworks are presented to facilitate the design and implementation of the water accounting. The benefits of a well-designed and well-implemented water accounting systems processes will enable to count and account of the water resources to achieve the sustainable water management. They can and should be used when developing and evaluating strategies for achieving water-related SDGs. Similarly, water accounting can be used for identifying and evaluating metrics aimed at monitoring press towards relevant water-related SDGs. However, a key point is that a water accounting system is much more than a set of models or algorithms. It is including institutional setting, system and data management system and team. A well designed and institutionalised water accounting system requires:

a) systems and/or platforms for acquiring and managing data and information;

b) a range of methods, models and tools for processing c) analyzing and interpreting of outputs;

d) a specialized team with relevant knowledge and experience (hydrology, hydrogeology, economy, environment, social, GIS, etc) who are located in the same office or working at different institutional levels in different regions of a country;

e) active engagement with key stakeholders and users who may share data and/or use water accounting outputs; and,

f) enabling institutional environment (soft and hard) for mandates and accountability.

Applying these frameworks will benefits to empower the water managers, user and the country to develop a tailored water accounting system, reporting on SDGs, and sustainably manage their water resources. Investments are really needed at the country level to be able to develop their tailored water accounting system that inform and evaluate their water resource plan.

\begin{tabular}{l} 
Your next submission with Juniper Publishers \\
will reach you the below assets \\
- Quality Editorial service \\
- Swift Peer Review \\
- Reprints availability \\
- E-prints Service \\
- Manuscript Podcast for convenient understanding \\
- Global attainment for your research \\
- Manuscript accessibility in different formats \\
( Pdf, E-pub, Full Text, Audio) \\
- Unceasing customer service \\
Track the below URL for one-step submission \\
https://juniperpublishers.com/online-submission.php \\
\hline
\end{tabular}

